\title{
The Development of Instructional Medium Based on E-learning in Taxation Subject at Economic Education Department, Jambi University
}

\author{
Suratno \\ Universitas Jambi \\ Jambi, Indonesia
}

\author{
Zuhri Saputra Hutabarat, Nurmala Sari \\ Universitas Jambi \\ Jambi, Indonesia \\ zuhri.saputra.hutabarat@gmail.com
}

\begin{abstract}
The aims of this research are to (1) develop an instructional medium based on E-learning in taxation subject at Economic Education Department; (2) improve the effectiveness of student learning in taxation subject by using E-learning. The results of the research as a whole, from the validation results by the material experts and multimedia experts shows that $E$ learning instructional medium developed is considered feasible. Based on the questionnaire of students' responses, E-learning is categorized into very reasonable criterion. In field trial to 25 students who contracted tax subjects, the average score of 61.8 from pre-test was obtained and the average score from post-test was 80.4. These results indicate that E-learning effectively improve student learning outcomes in taxation subject. Based on the results, the E-learning instructional medium can be utilized by lecturers and students in the learning process in order to make the learning of taxation subject on Economic Education Department more interesting. Utilization of E-learning in the subject of taxation for students Economic Education Department is as one of sources of active and independent learning. The development of E-learning needs to be studied in further research.
\end{abstract}

Keywords - media instruction, taxation, E-learning

\section{INTRODUCTION}

Scientific and technological revolution, community change, understanding of student learning, and progress of communication and information media gives meaning for educational activities. The challenge is one of the fundamental reasons for the technological approach in managing education and teaching. In addition, education as part of culture is a means of succession of values and ideas so that everyone is able to participate in the transformation of values for the betterment of the nation and state. Therefore, to realize a quality education, one that must exist is a qualified educator. Quality education is the one that has the ability to realize the goals of national education, which has the pedagogic competence, personal competence, social competence, and professional competence [1].

Each tax form has different uses, steps and procedures of calculation. Therefore, to understand a material is not possible with a single reading. Both understanding and the facts will soon be forgotten because they have not been embedded in the memory. That is why the materials should be learned repetitively, both material understanding and practice of calculation, so students obtain a correct understanding of the taxation lectures. This is in line with the results of interviews conducted to lecturers of taxation subject in the Economic Education Department of Jambi University, which revealed the difficulties experienced by students on the calculation and understanding of tax regulations. The learning results of taxation students at the Economic Education Department at the even semester 2013-2014, 2014-2015, and 2015-2016 from Information System of Jambi University (Siakad UNJA) are summarized in the following Table 1.

TABLE 1 ReCAPITULATION OF THE LEARNING RESUlts OF TAXATION COURSE

\begin{tabular}{|c|c|c|c|c|c|c|c|}
\hline \multirow{2}{*}{$\begin{array}{l}\mathrm{N} \\
\mathrm{O}\end{array}$} & \multirow{2}{*}{ Score } & \multicolumn{2}{|c|}{$\begin{array}{c}\text { Even Semester } \\
2013 / 2014 \\
\end{array}$} & \multicolumn{2}{|c|}{$\begin{array}{c}\text { Even Semester } \\
2014-2015 \\
\end{array}$} & \multicolumn{2}{|c|}{$\begin{array}{c}\text { Even Semester } \\
2015-2016 \\
\end{array}$} \\
\hline & & $\begin{array}{c}\text { Number } \\
\text { of } \\
\text { Students }\end{array}$ & $(\%)$ & $\begin{array}{c}\text { Number } \\
\text { Of } \\
\text { Students }\end{array}$ & $(\%)$ & $\begin{array}{c}\text { Number } \\
\text { Of } \\
\text { Students }\end{array}$ & $(\%)$ \\
\hline 1 & $\mathrm{~A}$ & 3 & 3.61 & 23 & 26.74 & 6 & 7.06 \\
\hline 2 & $\mathrm{~B}+$ & 4 & 4.82 & 9 & 10.47 & 12 & 14.12 \\
\hline 3 & B & 3 & 3.61 & 7 & 8.14 & 15 & 17.65 \\
\hline 4 & $\mathrm{C}+$ & 17 & $\begin{array}{l}20.4 \\
8 \\
\end{array}$ & 7 & 8.14 & 4 & 4.71 \\
\hline 5 & $\mathrm{C}$ & 45 & $\begin{array}{l}54.2 \\
2 \\
\end{array}$ & 6 & 6.98 & 19 & 22.35 \\
\hline 6 & $\mathrm{D}+$ & 3 & 3.61 & 13 & 15.12 & 9 & 10.59 \\
\hline 7 & $\mathrm{D}$ & 1 & 1.20 & 8 & 9.30 & 9 & 10.59 \\
\hline 8 & $\mathrm{E}$ & 7 & 8.43 & 13 & 15.12 & 11 & 12.94 \\
\hline \multicolumn{2}{|c|}{ Total } & 83 & 100 & 86 & 100 & 85 & 100 \\
\hline
\end{tabular}

Source: Administration of Economic Education Department (2017)

Based on the students' learning results at Economics Education Department for 3 semesters, most of the students obtained the $\mathrm{C}$ score and even there were still students who obtained the E score (failed). The high number of students who obtained bad score will affect grade point average (GPA). Consequently, this will affect the quality of graduates in the Economic Education Department, and the students with poor 
GPA will encounter obstacles in getting job or continuing to study at the next level. In addition, those who get a D or even E score are required to retake the course of taxation in the upcoming semester and it takes time and cost. In relation to these problems, the learning management model that is centered on students can be used as an option. Lecturers will act as facilitators in order to support students' motivation and creativity improvement. Students' independence is continually grown and motivated by changing the pattern of multi-way interaction. E-learning is aimed at providing broader education services, richer learning experiences, with all the implications for institutions, management systems, and well-prepared learning processes. Besides, E-learning as an application of information and communication technology that can train skills, critical thinking skills and technology literacy as well as facilitate the delivery of materials to students. Implementing E-learning for today's online learning is easy by utilizing the easy-to-install and manageable Learning Management System module like Moodle. Learning Management System (LMS) is software used to create online lecture materials based on the web and manage learning activities and their results. LMS also has features that can meet all the needs of users in terms of learning.

Moodle is a software package produced for internet-based learning activities and websites. Moodle is available and can be used freely as an open source product (open source program). The open source (Moodle) E-learning system used for learning media is expected to improve the efficiency and effectiveness of teachers' performance and learners' understanding of learning materials. The term Moodle stands for Modular Object Oriented Dynamic Learning Environment which means a dynamic learning place by using objectoriented model or is a package of web-based educational environment that is dynamic and developed with objectoriented concept. Moodle provides a complete software package such as Apache, MySQL, and PHP. By considering this background, a development of learning media is needed to help the students to understand the subject of taxation better. The development of learning media is also necessary to assist the lecturers in delivering the materials by using E-learning which is expected to present a more effective and interactive media information. Thus, the media are displayed not only in text form, such as books, newspapers, magazines, and so on but also in the form of audio, animation, and graphics (photo / picture).

Based on the background that has been described, the research problem was formulated as follows: 1) how can instructional medium based on E-learning on Taxation subject at Economic Education Department FKIP Jambi University be developed? 2) Does the development of instructional medium based on E-learning on Taxation subject at Economic Education Department FKIP Jambi University improve the effectiveness of student learning?

\section{METHOD}

Development model is the basis for developing a product. This research focused on the development of instructional medium based on E-learning on taxation subject at Economic Education Department FKIP Jambi University. The development of E-learning-based instructional medium was performed by using the multimedia instructional design development model developed by Lee and Owens (2004. Broadly speaking, this development model consists of five stages: (1) Stage Analysis (Analysis), (2) Design Stage (Design), (3) Development Stage, (4) Implementation Stage, and 5) Evaluation phase.

This model is used in the development of E-learning based on the following points. This model is procedural, that is descriptive, showing clear and careful steps to produce the product. The development stages in this model are the same as the standard development stage. However, this model is specifically designed for multimedia-based learning. This is in accordance with the product to be developed. The stages of developing E-learning based instructional medium with Moodle application model [2].

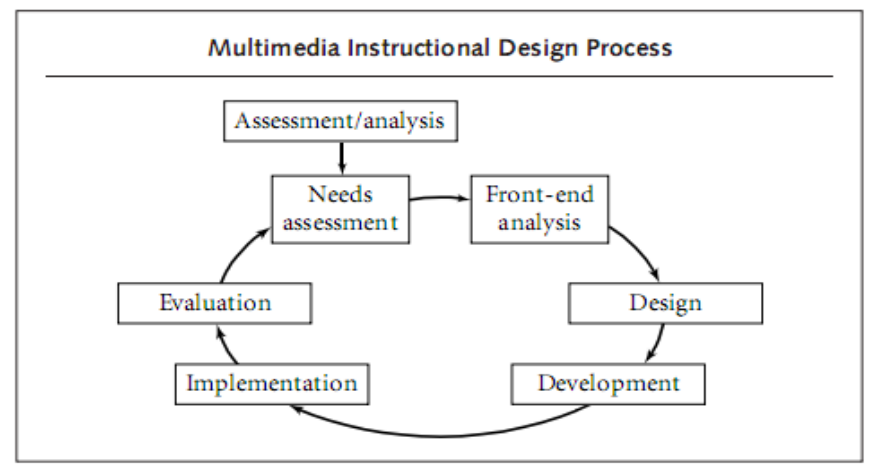

Fig. 1. The process of developing multimedia learning [2]

\section{RESULT AND DISCUSSION}

\section{A. Specification of E-learning Development Results}

The display of the medium can be seen by accessing portal address: https://perpajakanfipunja.id and clicking view (home). The manual to access the portal address is as follows:

Step 1: Access E-learning via the address: https://perpajakanfkipunja.id on your chrome, firefox, or Internet Explorer browser. The initial view of the development of E-learning based instructional medium can be seen in the following fig 2 .



Fig 2. The initial display (front page) 
Step 2: Select the login menu (login) on the dashboard in order that the login menu display appear. If not registered as a participant course, then register yourself by clicking menu "please register to be a new member (create new account)". Fill the identity data by filling out the information required on the provided column. If you have difficulties, contact the available phone number and e-mail at the right corner of the portal.

Step 3: If the student is registered, enter the registered user ID and password. Then click "sign in".

Step 4: Click one of the materials to be studied, then click download, wait until the material appears on the computer screen. Students can read or store the material on their respective computer drives.

Step 5: Students can continue by choosing other facilities such as learning videos, reading articles and discussing them through discussion forums, or glossary that has been provided on E-learning by clicking one of them.

Step 6: Furthermore, students can work on quiz questions offered. Each quiz can be done if the access schedule has been opened by the lecturer/admintration. For multiple choice quiz type (Quiz 1 and 4) and true-false (Quiz 3), the automatic value will appear after the student completes all the questions given. Problem will be presented in random form. As for the quiz type that requires uploading the answer (Quiz 2), the value will appear after the answer is checked and assessed by the lecturer.

Step 7: After you finish using this E-learning tax the student clicks "log out / exit" at the top right corner of the screen (reversed triangle logo next to name and profile photo).



Fig 3. The initial display (front page)

\section{B. Data Analysis}

\section{1) Analysis of Material Validation Results}

The material validation toward E-learning based instructional medium was conducted by material experts using 22 items of statements related to the content of the material on the medium and its feasibility to be tested. From the assessment of material experts from several indicators, the score was 83 obtained from the total score of 88 where the highest score of each item was 4 . The feasibility of the instructional medium is as follows.

$$
\begin{aligned}
& P=\frac{\sum X}{\sum X i} \times 100 \% \\
& P=\frac{83}{88} \times 100 \% \\
& P=94,3 \%
\end{aligned}
$$

By looking at the score of $94.3 \%$ from the results of material expert validation, it can be concluded that the material on the E-learning medium is categorized as very feasible/good, so E-learning is worthy of use as a medium of learning taxation. Comments and suggestions from the material experts in the questionnaire statement are taken into consideration for the improvement of the instructional medium.

\section{2) Analysis of Multimedia Validation Results}

To validate the multimedia aspect of the product, multimedia expert validation was conducted by using 18 items of statements related to the feasibility of the instructional medium. The score from the results of multimedia expert validation was 56 of the total score 72, where the highest score of each item was 4 . The feasibility of the instructional medium in terms of multimedia is as follows.

$$
\begin{aligned}
& P=\frac{\sum X}{\sum X i} \times 100 \% \\
& P=\frac{56}{72} \times 100 \% \\
& P=76,4 \%
\end{aligned}
$$

The score suggests that the multimedia on the E-learning medium is categorized as very feasible/good, so E-learning is worthy of use as a medium of learning taxation. Comments and suggestions from the material experts in the questionnaire statement are taken into consideration to revise the medium.

\section{3) Individual Trial Results}

The individual trial was conducted by using 10 items of statements related to the feasibility of E-learning medium toward 5 students. Of the several indicators, score of 173 was obtained of the total core, where the highest score of each item was 4 . The feasibility obtained from the results of individual trials is as follows:

$$
\begin{aligned}
& P=\frac{\sum x}{\sum x i} \times 100 \% \\
& P=\frac{173}{200} \times 100 \% \\
& P=86,5 \%
\end{aligned}
$$

The results of individual trials showed that the developed E-learning medium was categorized into good category, so the E-learning instructional medium is worthy of use as a medium of learning taxation. Comments and suggestions from trial participants (students) in the questionnaire statement are taken into consideration for improvement.

\section{4) Analysis of Small Group Trial Results}

Ten items of statements related to the feasibility of Elearning media were developed for small group trial toward 15 students. The score obtained from this trial was 527 from the total score, where the highest score of each item was 4 . The 
feasibility obtained from the results of small group testing is as follows:

$$
\begin{aligned}
& P=\frac{\sum x}{\sum x i} \times 100 \% \\
& P=\frac{527}{600} \times 100 \% \\
& P=87,8 \%
\end{aligned}
$$

The score of $87.8 \%$ obtained from the results of small group trials indicated that the developed E-learning medium had good category, so that the medium is worthy of use as a medium of taxation learning. Comments and suggestions from trial participants (students) in the questionnaire statement are taken into consideration for improvement.

\section{5) Analysis of Large Group Trial Data}

Ten items of statements related to the feasibility of the Elearning instructional medium were developed for large group trial by involving 25 students. From some indicators, the score obtained was 883 from the total score. The feasibility obtained from the results of large group trials is as follows:

$$
\begin{aligned}
P & =\frac{\sum X}{\sum X i} \times 100 \% \\
P & =\frac{883}{1000} \times 100 \% \\
P & =88,3 \%
\end{aligned}
$$

The calculation resulted in $88.3 \%$ in which it can be concluded that the developed E-learning medium had good category, so E-learning instructional medium is worthy of use as a medium of learning taxation. Comments and suggestions from trial participants (students) in the questionnaire statement are taken into consideration for improvement.

\section{6) Data Analysis based on Observation of Students}

Based on the observation of the students in using Elearning related to the attractiveness, ease, efficiency and effectiveness, all students showed the attitude of self-reliance learning, studied the material in sequence according to the instruction of learning, and did Quiz questions provided seriously. However, there were some students who did not use the live chat facility and discussion forum and the students who switched by using internet facility for other activities (watching YouTube).

\section{Product Revisions}

\section{1) Revisions based on Material Expert Validation Results}

\begin{tabular}{|c|c|c|}
\hline No & Expert's Feedback & Improvements \\
\hline 1. & $\begin{array}{l}\text { Group A No. } 6 \text { on the } \\
\text { reversed statement should } \\
\text { be corrected. }\end{array}$ & $\begin{array}{l}\text { The statement on the questionnaire } \\
\text { is replaced with 'an indicator } \\
\text { according to the basic } \\
\text { competencies' }\end{array}$ \\
\hline 2. & $\begin{array}{l}\text { Group B No. } 8 \text { in the } \\
\text { questionnaire uses the } \\
\text { term according to the } 2013 \\
\text { curriculum }\end{array}$ & $\begin{array}{l}\text { The statement on the questionnaire } \\
\text { is fixed: Relevance of learning } \\
\text { objectives with KI, KD and } \\
\text { Indicators. }\end{array}$ \\
\hline
\end{tabular}

Based on the validation result from the material expert, there are several revisions made to the questionnaire related to the assessment of taxation material as follows:

TABLE 2 REVISION BASED ON MATERIAL EXPERT VALIDATION RESULTS

\section{2) Revisions based on Media Expert Validation Results}

Revisions are also made to the developed media of taxation. Based on the results of validation conducted by the learning media experts, E-learning based instructional medium should be revised before the field trial.

TABle 3 REVISION BASEd ON MEDia EXPERT VALIDATION RESUlts

\begin{tabular}{|l|l|l|}
\hline No & Expert Advice Field Study & \multicolumn{1}{|c|}{ Improvements } \\
\hline 1. & $\begin{array}{l}\text { The cover design on the } \\
\text { dashboard is less beautiful, } \\
\text { less attractive, and ordinary. } \\
\text { Compare with tax amnesty } \\
\text { dashboard. }\end{array}$ & $\begin{array}{l}\text { The improvements are changing the } \\
\text { display of the front image, adding } \\
\text { the icon / image according to the } \\
\text { menu material, articles, glossary and } \\
\text { quiz and putting the login page after } \\
\text { the dashboard. }\end{array}$ \\
\hline 2. & $\begin{array}{l}\text { The background should not } \\
\text { be white, and it needs to be } \\
\text { animated appropriately. }\end{array}$ & $\begin{array}{l}\text { Background color cannot be } \\
\text { changed because the background } \\
\text { color of moodle application has been } \\
\text { set according to the chosen theme. }\end{array}$ \\
\hline
\end{tabular}

The front view (dashboard) on E-learning based instructional medium before revision and after revision based on suggestions and improvements of multimedia learning experts can be seen in fig 4 .
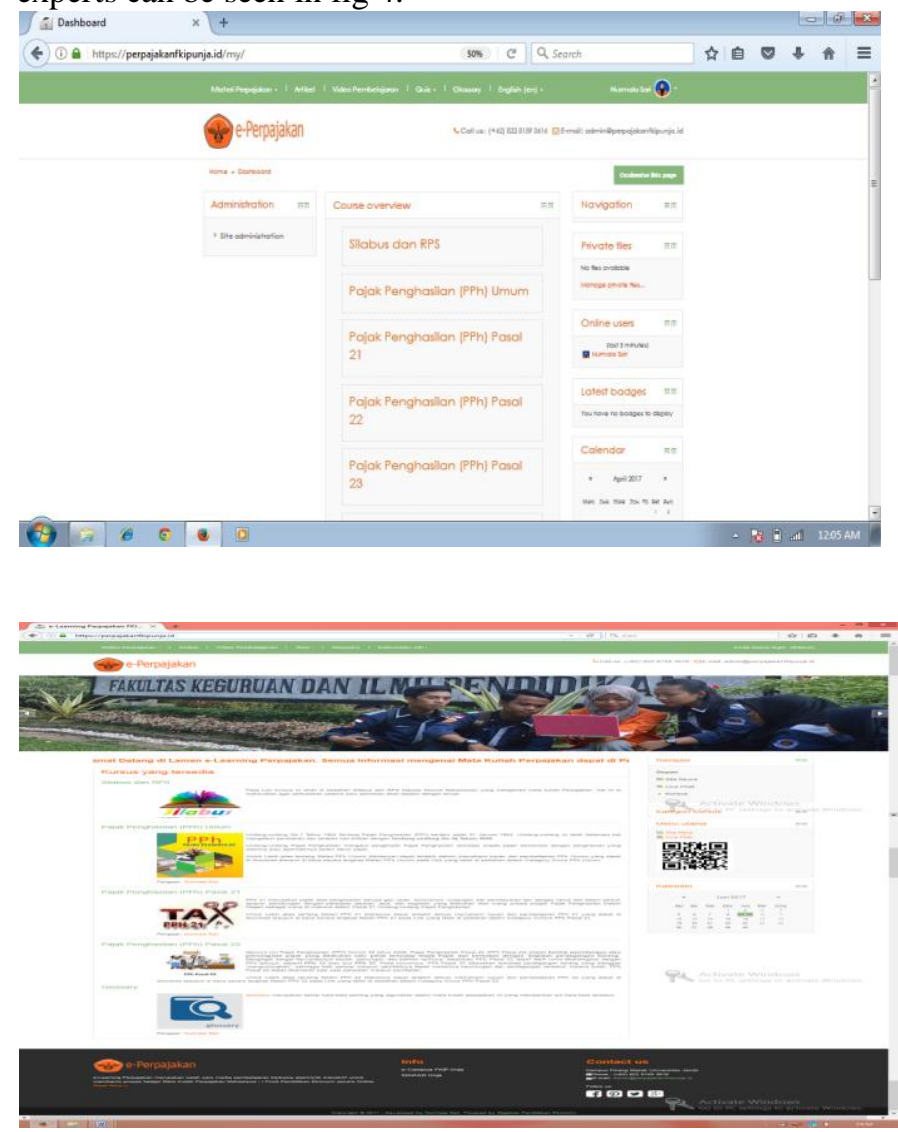

Fig. 4. Dashboard View after Revision

3) Revisions based on Individual Trial Results

Based on the results of individual trials to 5 students, suggestions and comments were obtained and used for the following revisions: 1) adding video of taxation, 2) fixing some typographical errors in Article 21. 
4) Product Revisions Based on Small Group Trial Results

Based on trials in small groups, there are some students' difficulties in accessing the quiz because they have not been enrolled as quiz participants. This can be solved by enrolling the test participants on the quiz through teacher / lecturers account.

\section{5) Product Revisions Based on Large Group Trial Results}

Based on trials in large groups, no revisions are required. There were only learners who have difficulty in filling out forms as new participants because the requested password must consist of a combination of letters, numbers, and characters. The rest of the students stated that the E-learning instructional medium is good enough but it needs to be improved again.

\section{Discussion of Final Items}

\section{1) Revised Product}

The development of E-learning based instructional medium in this taxation course is based on the fact that the progress in the field of Technology, Information and Communication era should be utilized in supporting the learning activities especially in the subject of taxation in order to facilitate the students in following and understanding the learning materials. The development process was carried out through 5 (five) stages: analysis phase, design phase, development stage, implementation phase and evaluation phase adapted from Lee and Owens' design model [2]. The resulting product has been evaluated through an expert test validation process, individual trials, small group trials and large group trials. Based on these assessments, improvements were made in terms of design, content, operations, and so on, resulting in a valid and effective product used in learning. Based on the test results, the quality of products can be described as follows: 1) Quality of media in terms of field of taxation studies based on the assessment of the validation results of experts in the questionnaire is categorized very feasible. Validation was done in one step, followed by revision, and it was declared feasible to be tested, 2) Quality of media in terms of multimedia learning aspects based on the assessment of expert validation results in the questionnaire was categorized feasible. However, based on multimedia expert' feedback, there are some points that should be revised, and then tested. 3) Based on questionnaires in three stages of testing conducted to students, developed media was declared very feasible.

\section{E. Use of Products}

The product developed for use as a learning medium is Elearning. E-learning system is a form of application of information technology intended to facilitate the process of learning that is packaged in the form of digital content and the implementation requires electronic means (laptop/computer/gadget) connected to the internet [3].

Based on the results of observations on individual trials, small groups, and large groups, there are still learners who do not utilize the time well in the learning process using Elearning due to operational difficulties. Difficulties are more individual, such as those who are less active in learning. Learners are not brave to experiment (trial and error) and tend to wait instructions and help from researchers or friends. Less active learners also only open the sections instructed, and do not use all the tools in E-learning (live chat, video, glossary, discussion forum) to the fullest. On the other hand, some other students without waiting for instructions from researchers directly explore the contents of E-learning and try all the tools or facilities and ask some questions about the use of which they do not understand. So, E-learning based instructional medium is suitable for learners who have an active attitude in learning, motivation and independence of learning, while for passive learners need more guidance in using the medium.

\section{F. Results of Product Use}

Learning outcomes obtained from the utilization of Elearning can only be seen from the results of cognitive learning alone. Based on the results of the test on large group trials, after pre-test and post-test on the learning of taxation to 25 students of Regular Economics Education Department semester 2, the average score from pre-test was 61.8 and the average score from post-test after using E-learning was 80.4. Based on the data of large group experiments, it can be concluded that the use of the developed E-learning based instructional medium effectively improve students' learning outcomes on taxation in Economic Education Department. This is in line with the results of research conducted by [4] who states that based on product effectiveness test results; there are significant differences in students' learning outcomes before and after using Moodle-based E-learning portal. The increase is seen from the analysis of pretest and posttest data, where the average pre-test score is smaller than the post-test average score, 63.90 versus 92.39 . The quality of student learning was affected by $78.5 \%$ of E-learning and the remaining $21.5 \%$ was influenced by other factors such as lecturer skills. Thus, it can be said that the utilization of Elearning used in the learning process turns out to have high attractiveness for learners, makes learning more fun because students feel a new nuance in the learning process and can improve learning outcomes [5].

\section{CONCLUSION}

Based on the process of developing E-learning instructional medium on taxation subject at Economic Education Department of Jambi University, this study employs Moodle version 2.9.2 and XAMPP applications to develop E-learning instructional medium with rent hosting on Rumah Web Indonesia. E-learning is designed in such a way as to facilitate students in understanding the taxation material. This E-learning instructional medium was developed through several stages, starting from the analysis phase to find out the needs of students related to learning media, the design phase including the activities of determining media specifications, making material structure, and planning configuration control. 
The next stage of development covers installation of the application, content uploading, and product validation by the material experts and multimedia learning experts. The validation process results in some improvement suggestions on the display and content of E-learning. Furthermore, at the implementation stage, trials were conducted to students three times, namely individual testing, small group trials, and field trials. From the three test results, the E-learning instructional medium is stated feasible for use in learning. The last stage was performed for the evaluation stage, namely by giving pretest and post-test to students who follow the taxation course. All suggestions from experts and respondents (students) used as a reference in revising E-learning developed so feasible to be used as a medium of learning taxation. 2) The use of Elearning-based learning media for students of Economic Education Department proved to improve the results of tax learning, this can be seen from the average score of the test grade tax assessment class test. The results were obtained from comparing the mean values of pre-test 61.8 and post-test with an average score of 80.4. These results indicate that Elearning developed proven to effectively improve student learning outcomes.

Due to the benefits of E-learning instructional media, it is suggested that lecturers can use such medium in the learning process to make learning process more interesting and varied. Students can also utilize the media as an alternative source of active and independent learning inside and outside the classroom. In order that active and independent learning proceed smoothly and attractively, pay attention to the minimum specifications required to operate this product. Moreover, further product development is expected not limited to E-learning based instructional media in taxation course, but also other subjects at college levels. The development of E-learning should not be only limited to the use of Moodle's LMS (learning Management System) application but also other applications with better results.

\section{REFERENCES}

[1] Anonim, UU RI Nomor. 14 tahun 2005 tentang Guru dan Dosen.

[2] W.W. Lee and D.L. Owens, Multimedia-Based Instructional Design, Computer Based Training, Web Based Training, Distance Broadcast Training, Permormance Based Solutions, Second edition, San Fransisco: Pfeiffer, 2004.

[3] Rusman, Pembelajaran Berbasis Teknologi Informasi dan Komunikasi, Jakarta: PT. Raja Grafindo Persada, 2011.

[4] Hartawan, I. K. Agus, I. D. K. Tastra, dan K. Pudjawan, Pengembangan Portal E-learning Berbasis Moodle pada Mata Pelajaran Fisika Kelas X di SMA, 2014

[5] E. Karwati, and D. J. Priansa, Manajemen Kelas Classroom Management Guru Profesional yang Inspiratif, Kreatif, Menyenangkan, dan Berprestasi, Bandung: Alfabeta, 2014 